\title{
White spruce understory protection: From planning to growth and yield
}

\author{
by Brigitte E. Grover ${ }^{1, *}$, Mike Bokalo² and Ken J. Greenway ${ }^{3}$
}

\begin{abstract}
A large component of the boreal mixedwood forest is comprised of aspen and white spruce mixtures of varying proportions and ages. The slower growing white spruce usually starts as an understory component but will succeed to a white sprucedominated stand after aspen break-up. Since both species are utilized by the forest industry, one method of maximizing total yield is to protect the unmerchantable white spruce understory while harvesting the merchantable aspen overstory. Although some of the white spruce understory is lost when the machine corridors are harvested, future conifer yield is augmented by the accelerated growth of the protected spruce component, a result of increased light levels. In a 10 year trial comparing the growth of released versus control understory spruce, annual height growth, diameter growth and volume increment were $76 \%, 152 \%$ and $83 \%$ higher, respectively, for the released conifer compared to the control. In order to account for the yield implications in timber supply analysis, accurate forecasts of future stand development can only be obtained through the use of a forest growth model since long-term data are not available. The Mixedwood Growth Model (MGM) has a unique architecture that allows for the modeling of various strata in understory protection stands. This "multi-strata" modeling approach was used to forecast the combined yield of all the strata, including the impact of adjacent strata with regards to light availability. Operational examples of understory protection, data on white spruce release and aspen regeneration, as well as modeled volume forecasts are presented.
\end{abstract}

Keywords: forest management, boreal mixedwood, harvesting systems, white spruce understory protection, white spruce release, growth and yield, Mixedwood Growth Model

\section{RÉSUMÉ}

Une grande partie des forêts mixtes boréales est formée de regroupements de tremble et dépinette dans diverses proportions et dâges variés. L'épinette blanche, à croissance plus lente, se présente d’abord en sous-étage, mais formera à terme un peuplement dominé par lépinette blanche après le déclin du tremble. Étant donné que ces deux espèces sont utilisées par linndustrie forestière, il serait possible de maximiser le rendement total en protégeant le sous-étage dépinette blanche, sans valeur marchande, lors de la récolte commerciale de la strate dominante de tremble. Même si une partie du sous-étage dépinette blanche devait être détruite dans les sentiers aménagés pour la machinerie au moment de la récolte, le rendement futur des résineux en serait accru dû à la croissance accélérée de la strate dépinettes protégée, en raison d’une plus forte luminosité. Dans un essai sur 10 ans destiné à comparer la croissance du sous-étage dépinette dégagé par rapport au témoin, la croissance annuelle en hauteur, la croissance en diamètre et laccroissement en volume ont été respectivement de $76 \%$, de $152 \%$ et de $83 \%$ plus élevés chez les épinettes dégagées comparativement au témoin. Pour tenir compte des implications qu’auront ces résultats sur le rendement dans les analyses d’approvisionnement et obtenir des prévisions précises du développement futur des peuplements, il faut nécessairement recourir à un modèle de croissance des peuplements puisqu'il n’y a pas de données à long terme disponibles. Le Mixedwood Growth Model (MGM) présente une architecture particulière lui permettant de modéliser différentes strates dans les peuplements dont le sous-étage est protégé. Cette approche de modélisation «multistrates » a été utilisée pour prédire le rendement combiné de toutes les strates, ainsi que les effets sur les strates adjacentes en matière de disponibilité de la lumière. Cet article propose des exemples concrets de protection du sous-étage, des données sur le dégagement de lépinette blanche ainsi que sur la régénération du tremble de même que des prévisions modélisées sur le volume.

Mots clés : aménagement forestier, forêt mixte boréale, système de récolte, protection du sous-étage dépinette blanche, croissance et rendement, Mixedwood Growth Model

\section{Introduction}

Alberta-Pacific Forest Industries' (Alberta-Pacific) Forest Management Agreement (FMA) area is located in the western Canadian boreal mixedwood forest, which is a mosaic of aspen (Populus tremuloides Michx.), balsam poplar (Populus balsamifera L.) and white birch (Betula papyrifera Marsh.) mixed with white spruce (Picea glauca [Moench] Voss) and jack pine (Pinus banksiana Lamb.) on upland sites, surrounded by vast areas of wetlands of sparse black spruce (Picea mariana [Mill.] BSP). The main natural disturbance agent is wildfire, which drives succession (Rowe and Scotter 1973, Johnson 1992). After fire, most upland sites regenerate to deciduous species through prolific suckering from roots, while coniferous species (usually white spruce) recruit into the understory from seed. The slower growing white spruce can remain in the understory for many decades but will eventually grow through the canopy to dominate the

\footnotetext{
${ }^{1}$ Alberta-Pacific Forest Industries, Box 8000, Boyle, Alberta T0A 0M0.

${ }^{2}$ Department of Renewable Resources, 751 General Services Building, University of Alberta, Edmonton, Alberta T6G $2 \mathrm{H} 1$.

${ }^{3}$ Alberta Research Council, Vegreville, Alberta. Current address: Environment and Sustainable Resource Development, Forestry Division, Forest Management Branch. 9920-108 Street, Edmonton, Alberta T5K 2M4.

${ }^{\star}$ Corresponding author. E-mail: gitte.grover@alpac.ca
} 
stand following aspen senescence (Chen and Popadiouk 2002). Eventually, most of the conifer leading stands will burn and restart the cycle.

Aspen stands that have conifer understories are quite common on Alberta-Pacific's FMA area. According to the Alberta Vegetation Inventory (AVI), approximately half of the pure deciduous stands have an identified white spruce understory and in about half of these stands the understories occur in densities greater than 600 stems/ha.

Since understory white spruce is not merchantable when the aspen overstory is optimally scheduled for harvest, logging systems have been developed that can extract the aspen while protecting the white spruce understory (Brace and Bella 1988, Sauder 1992, Navratil et al. 1994). An important factor in these harvest systems is to maintain a small aspen component either in strips or randomly distributed (Keddy and Sidders 2007, MacIsaac and Krygier 2009, Lennie et al. 2009) to provide a buffer and reduce the potential for windthrow of the released white spruce.

An added benefit to the aspen volume recovery in these systems is the release and accelerated growth rates of white spruce following overstory removal. White spruce growth is suppressed in the understory due to reduced light levels (Lieffers and Stadt 1994, Filipescu and Comeau 2007) and the trees are often subjected to physical abrasions and leader whipping from aspen crowns (Lees 1966, Steneker 1967). After aspen overstory removal, white spruce releases regardless of age; however, several reports indicate that trees aged 20 to 60 years are most responsive (Steneker 1963, Lees 1966, Yang 1989).

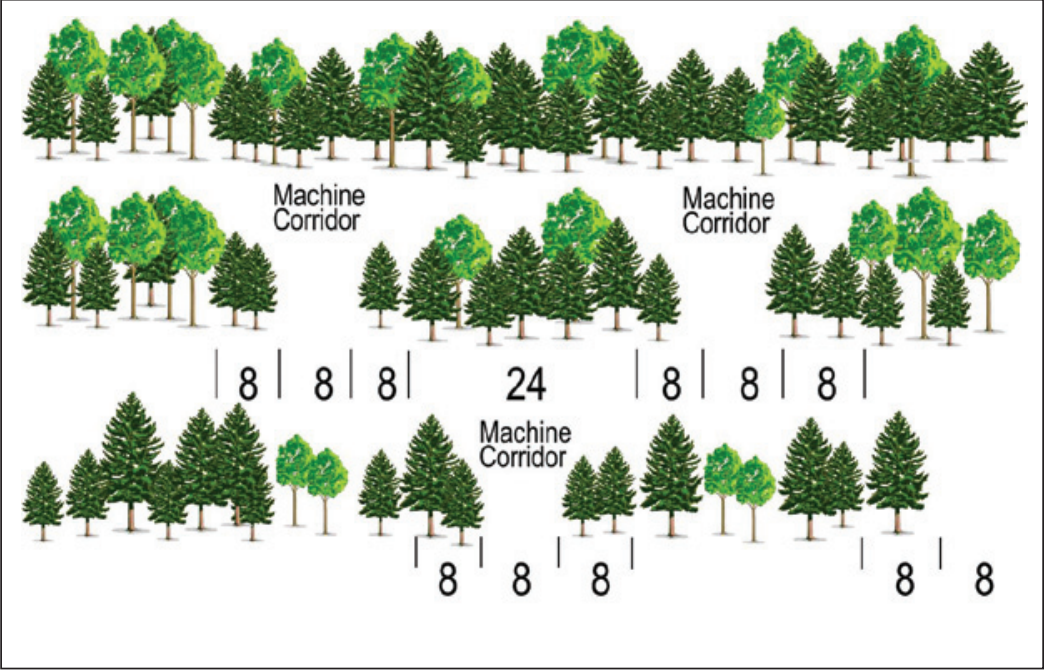

Fig. 1. Two-pass strip cut understory protection harvest pattern.

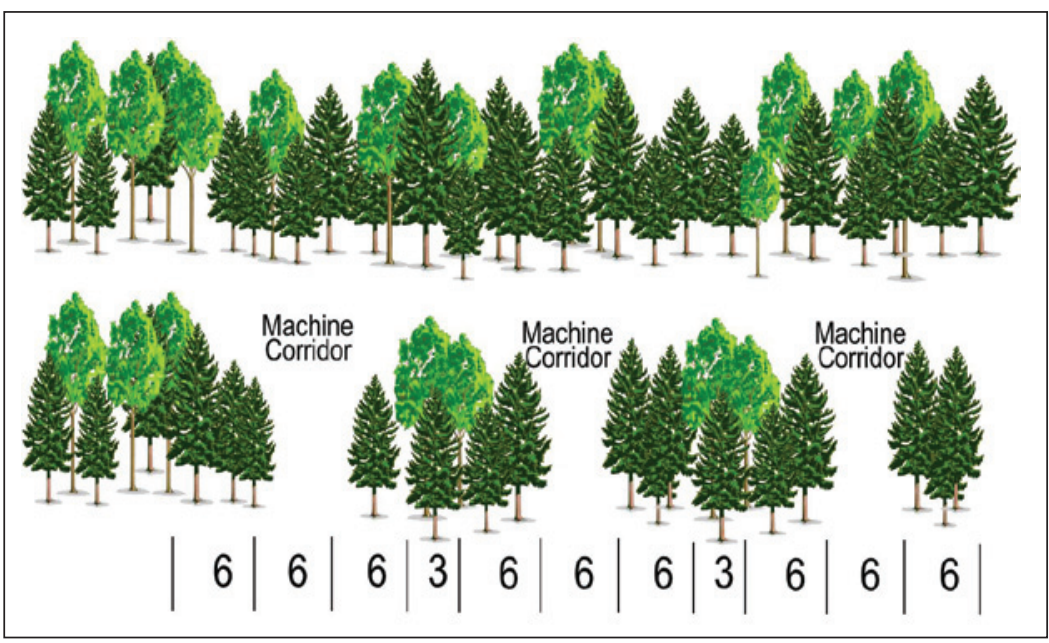

Fig. 2. Single-pass strip cut understory protection harvest pattern.

Notably accelerated growth rates have been

reported after release, with diameter growth usually responding more significantly than height growth, and total annual volume increment increasing up to $93 \%$ as compared to the unharvested control (Lees 1966; Yang 1989, 1991; Man and Greenway 2004).

The objective of this paper is to describe the methodology of understory protection that has been implemented operationally in the Alberta-Pacific FMA area, show the resulting impacts on tree growth, and discuss the potential effects on future yields in these complex, post-understory protection stands.

\section{Methods}

\section{Study area and harvest systems}

White spruce understory protection was first achieved through strip harvesting methods modelled after one of the designs utilized at the Hotchkiss trial (Navratil et al. 1994). The original two-pass system restricted all machine traffic to an $8-\mathrm{m}$ wide corridor (Fig. 1). A feller-buncher traveling on this corridor would reach $8 \mathrm{~m}$ to either side extracting only the deciduous component. A 24-m-wide unharvested strip (residual) would be retained between adjacent extraction strips to protect spruce from blowdown. The intent of this design was to return in five

to 10 years after the spruce had become windfirm and place an 8-m machine corridor and two 8-m extraction areas into the 24-m-wide unharvested residual area to extract the remaining deciduous trees. The design currently used operationally is a single-pass system (Fig. 2). It employs a $6 \mathrm{~m}$ wide machine corridor, two $6 \mathrm{~m}$ wide extraction areas and a $3 \mathrm{~m}$ wide residual strip for wind protection. This design eliminates the need to maintain roads and culverts for the second entry, the shorter reach is easier on equipment, and a narrower machine corridor protects more of the resource.

The research trial cutblock that will be referred to throughout this paper is located in the Calling Lake area in northeastern Alberta, Township 73, Range 22, west of the 4th Meridian. The stand was 77 years old at time of harvest, with an aspen overstory of 682 stems/ha and a white spruce understory of 724 stems/ ha. The average height of the aspen overstory was $22 \mathrm{~m}$ and the average height of the white spruce understory was $10 \mathrm{~m}$. Using the two-pass harvest design, a 58-ha cutblock was harvested in February of 1997, leaving approximately 25 ha un-harvested as a control (Fig. 3). The strips were oriented north-south perpendicular to prevailing winds to enable the residual strip to protect the understory spruce from blowdown. 


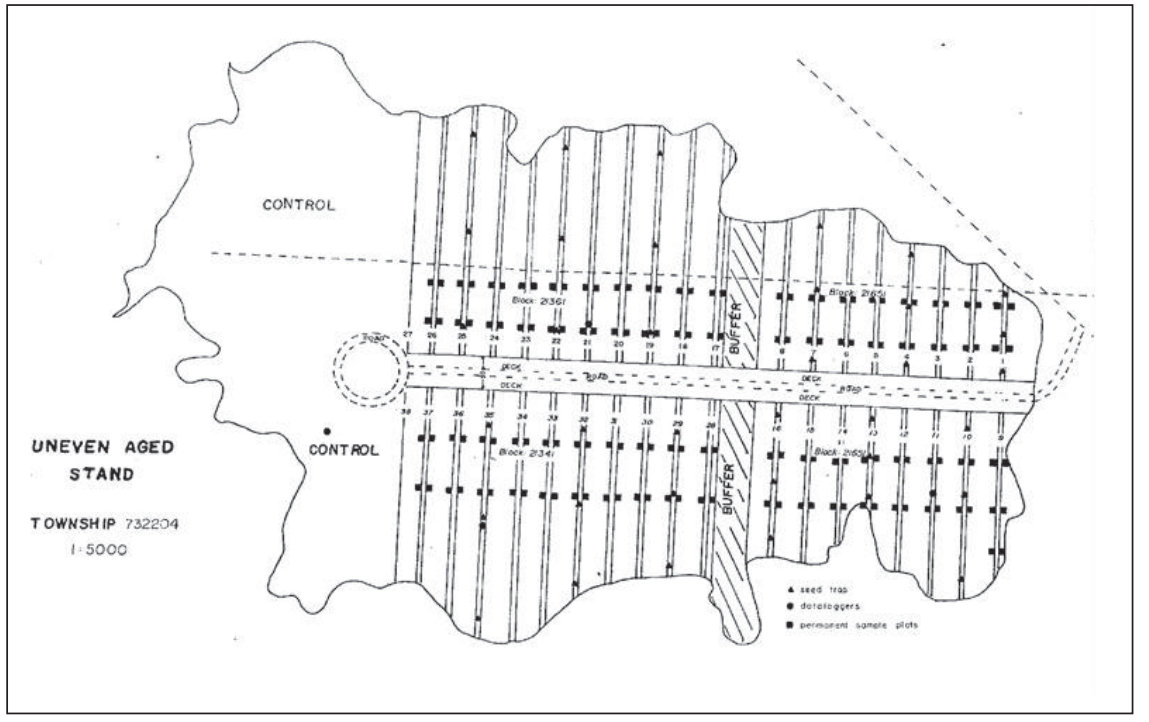

Fig. 3. Schematic of research understory protection block.

\section{Data sources}

Prior to harvest, the research stand was surveyed systematically on a $100-\mathrm{m}$ grid using $3.99 \mathrm{~m}$ radius plots. All trees (overstory and understory) were tallied by species, and diameter and height measurements were taken for three randomly selected trees of each species in each plot.

To quantify white spruce release response, eighty $8 \times 8 \mathrm{~m}$ Permanent Sample Plots (PSPs) were established in the extraction area and 50 were established in the control area. Location, height and diameter of the trees were measured in 2000, 2005 and 2010. Data were used to compile statistics on height, diameter and gross volume for understory conifer (control vs. release) $)^{1}$. To evaluate aspen regeneration and growth on machine corridors as well as road and decking areas, performance regeneration surveys as per the Regeneration Standards of Alberta (RSA) (Alberta Environment and Sustainable Resource Development 2011) were completed in 2011.

\section{Mixedwood Growth Model}

The Mixedwood Growth Model $^{2}$ (MGM) is a deterministic, distance-independent, individual tree growth model developed by the University of Alberta for the western Canadian boreal forest (Bokalo et al. 2013). MGM is designed to model yield for simple or complex multi-species, multi-cohort stands of trembling aspen, white spruce, lodgepole pine and their mixtures. Individual tree height and diameter growth are estimated using regional site index curves, allometric allocation functions, and empirically derived functions to account for effects of competition from overtopping trees. The MGM Adjacency Model can further reduce the growth of trees based on the shading effect from adjacent strata. The light reaching any given stratum is determined using MixLight (Stadt and Lieffers

${ }^{1}$ Differences between control and released white spruce were subjected to $t$-tests.

${ }^{2}$ The Mixedwood Growth Model (MGM) referenced in this manuscript relates to MGM2010.xls and its supporting MGM HelpWeb documentation available online: http://www.rr.ualberta.ca/ Research/MixedwoodGrowthModel.aspx
2000) in a pseudo-spatial approach that arranges each of the corridors within the block.

\section{Modelling understory protection with MGM}

Inputs were constructed to spatially mimic the current harvesting pattern (6 $\mathrm{m}$ wide extraction area; $6 \mathrm{~m}$ wide machine corridor; $6 \mathrm{~m}$ extraction area; $3 \mathrm{~m}$ residual strip). The machine corridors were initialized using data acquired from machine corridor regeneration surveys. The extraction areas were initialized with plot data from the extraction area PSPs (release data) and the residual areas with data from the pre-harvest timber cruise. The final polygon projected was comprised of $57 \%$ extraction area, $29 \%$ machine corridors and 14\% residual strips. Since no long term PSP data are yet available from the current operational singlepass design, data from the first pass of the two-pass design were used. Although the widths of the three strata differ between the two designs, the regeneration, release and adjacency effects are expected to be similar.

Projections began post-harvest using the first plot measurement $(2000$; stand age $=80)$ to initialize each stratum. The central mixedwood natural sub-region, the regional site index equations (Huang 1997, Huang et al. 1997) and the volume equations (Huang 1994) were set as run parameters. Site index was set to $14 \mathrm{~m}$ for white spruce and $22 \mathrm{~m}$ for aspen based on past experiences for stands in the Alberta-Pacific FMA area. Each stratum was projected forward 10 years to the remeasurement date where the actual observed stand conditions were evaluated against the MGM predictions. The projections were allowed to continue for another 50 years to a stand age 140. To contrast the effect of strip cut patterns on spruce and aspen growth and yield, two projections, with and without adjacency, were carried out.

\section{Results}

\section{Operational practices}

Alberta-Pacific has been employing strip cut understory protection operationally since 2000. After harvest of the initial two-pass research block, a single-pass system was chosen for subsequent blocks for ease of logistics since returning to the block for a second harvest phase is not operationally practical. A field based pre-harvest assessment system was developed to categorize understories identified through the Alberta Vegetation Inventory or during cutblock layout. Circular plots with a $3.99 \mathrm{~m}$ radius are established on a $100 \times 100 \mathrm{~m}$ grid throughout the stand. In each plot, tallies for understory species by height class, as well as crown class, disease, aspect and slope are recorded. The information is used to identify plots with healthy white spruce at densities of greater than $600 \mathrm{stem} / \mathrm{ha}$. Three consecutive plots with densities of greater than $600 \mathrm{stems} / \mathrm{ha}$ are needed to make the strip cut harvest system operationally feasible. Areas with plots that have densities less than 600 stems/ha are assigned to understory avoidance harvest, where logging operators protect 


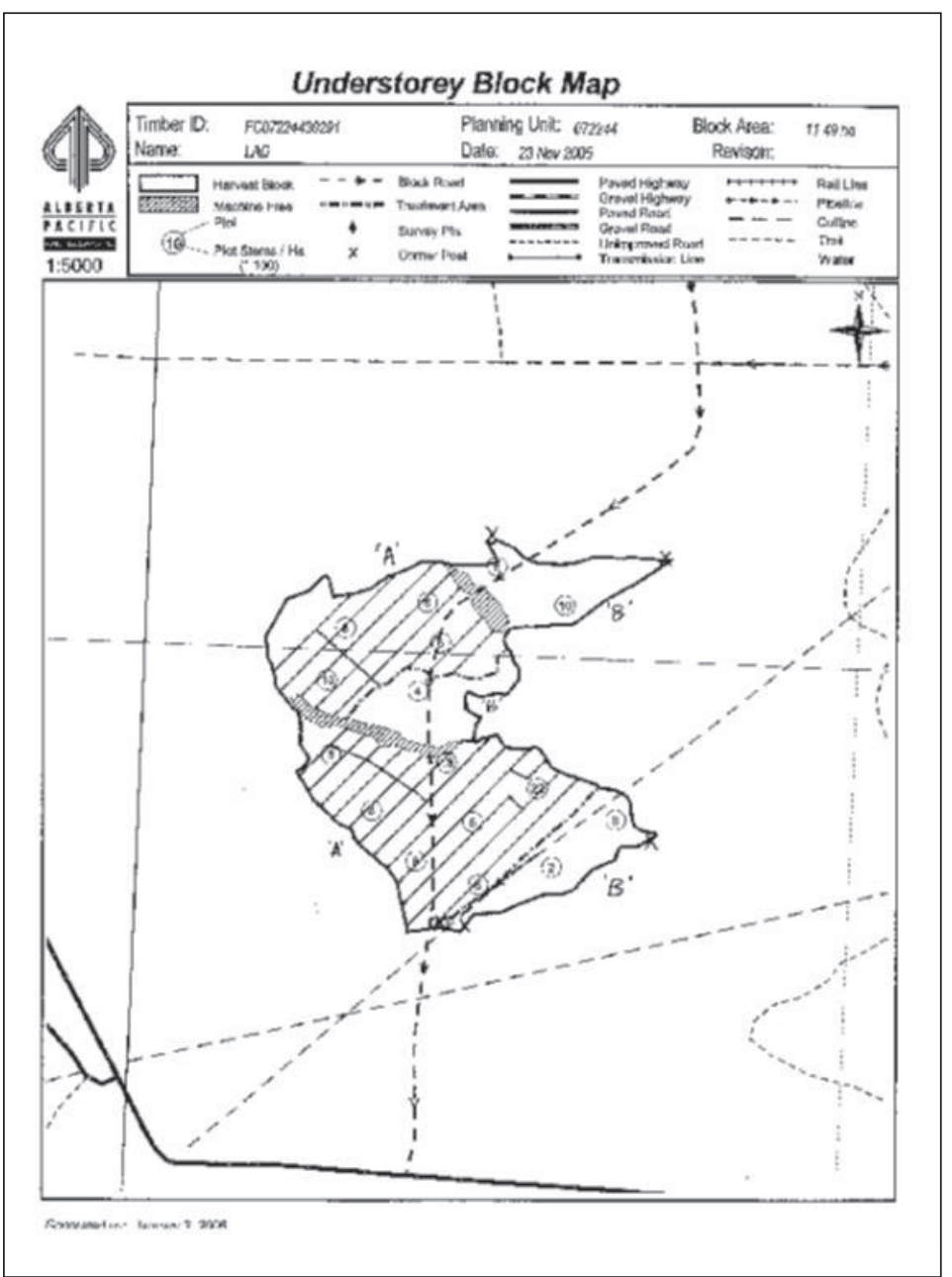

Fig. 4. Understory protection detailed block map.

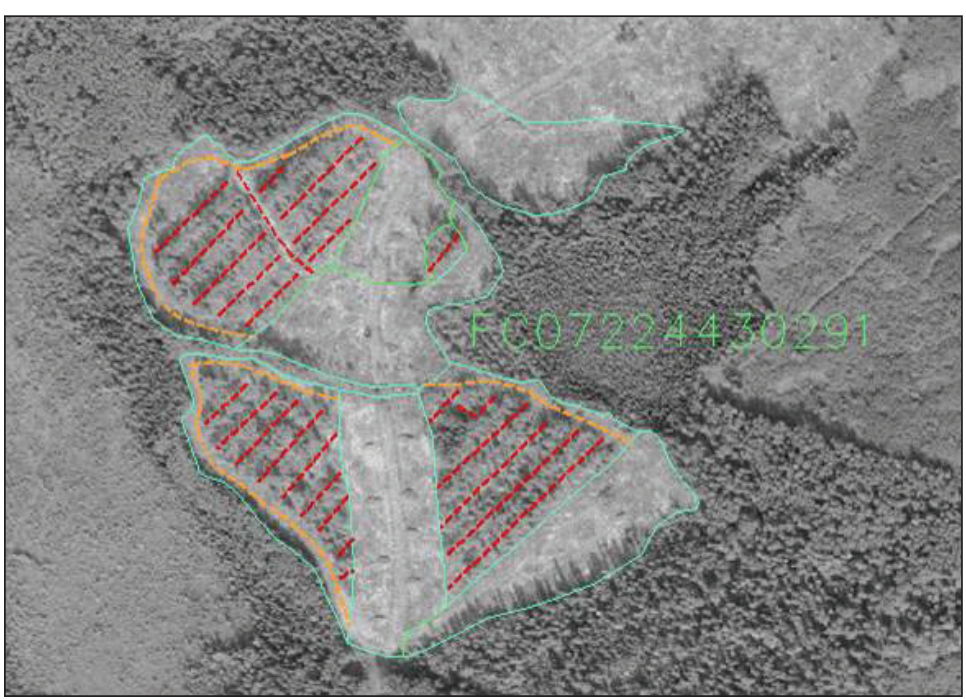

Fig. 5. Post-harvest update photography delineating machine corridors and non-strip areas. the white spruce understory without a specific design or pre-harvest layout. A detailed block map is created from the pre-harvest assessment plots that shows areas of strip harvest, avoidance harvest or clearcut and the location of roads and decking areas (Fig. 4). The map allows planners to calculate area in various strata, and guides the layout crew and harvest contractors during operations.

Using aerial photography obtained one or two years after harvest, the strata shown on the preharvest map are identified using digital imagery processing (Fig. 5), and the area in roads and decking areas, machine corridors, backline and the actual area with protected understory is mapped. Pre- and post-harvest maps can be compared for reconciliation and evaluation of operational "success".

\section{Release and regeneration}

Understory protection strip harvesting creates a complex stand with several spatially segregated post-harvest strata. The first stratum is the extraction area that contains protected spruce where the aspen overstory has been removed. The second stratum is the area where all trees were removed, such as machine corridors, backlines, roads and decking areas. The third stratum is the residual strip that has spruce understory plus retained aspen overstory. The aspen in the residual strip will not be available for harvest at next rotation, which is scheduled to occur no earlier than 60 years after the understory protection harvest to ensure merchantability of the regenerating deciduous layer.

Results from three PSP measurements in fiveyear intervals in the control and extraction area are shown in Fig. 6 to Fig. 11. Height growth accelerated significantly for the released white spruce, starting immediately after harvest as is seen in the first five year period (Fig. 6). Overall, in 10 years the height growth increased $76 \%$ over that of the control. Diameter growth shows an even stronger response to overstory removal, with an average $152 \%$ increase (Fig. 7). Gross volume increment in released spruce was $83 \%$ greater than the control trees over the 10 year measurement period (Fig. 8). When release is assessed by height classes, height growth accelerated most in the smallest height class $(5-10 \mathrm{~m})$ and least in the tallest height class $(>20 \mathrm{~m})$ (Fig. 9). This trend is not seen in diameter growth (Fig. 10), which increased to approximately the same degree in all height classes. All height, diameter and volume differences between control and released spruce were significantly different at $P<0.05$, except for height increment in the $>20 \mathrm{~m}$ height class.

Aspen regeneration in machine corridors, roads and decking areas was within range of regeneration parameters found in clear-cuts ${ }^{3}$ with an

${ }^{3} 40$ blocks, surveyed in 2011 at year 14 , average density ranged from 


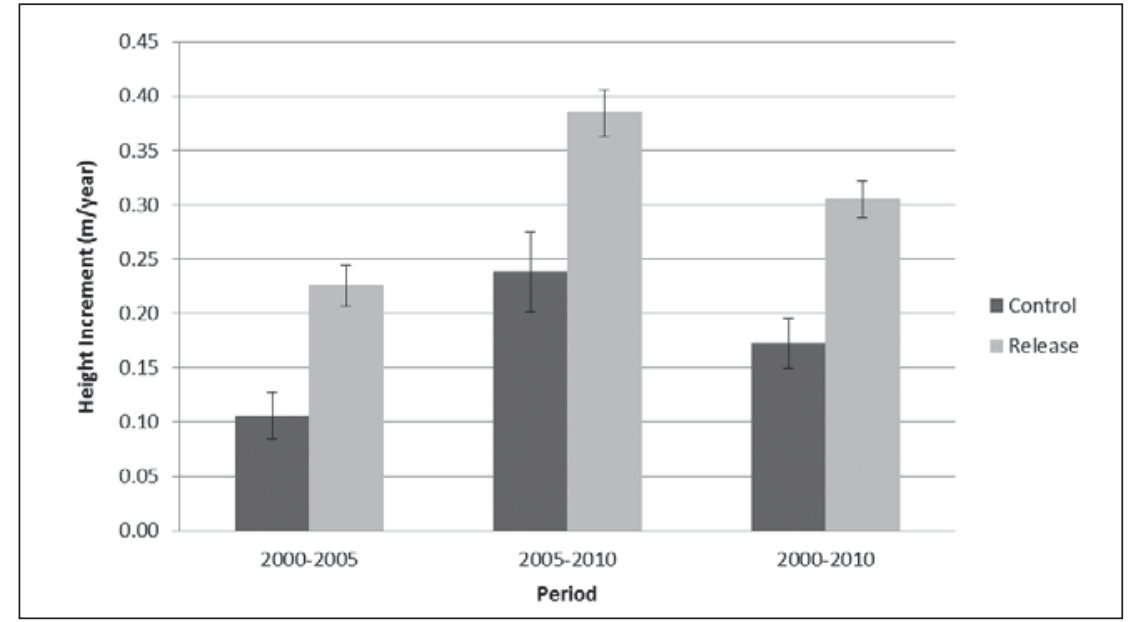

Fig. 6. Annual height growth of released and control understory white spruce. Error bars represent the $95 \%$ confidence interval.

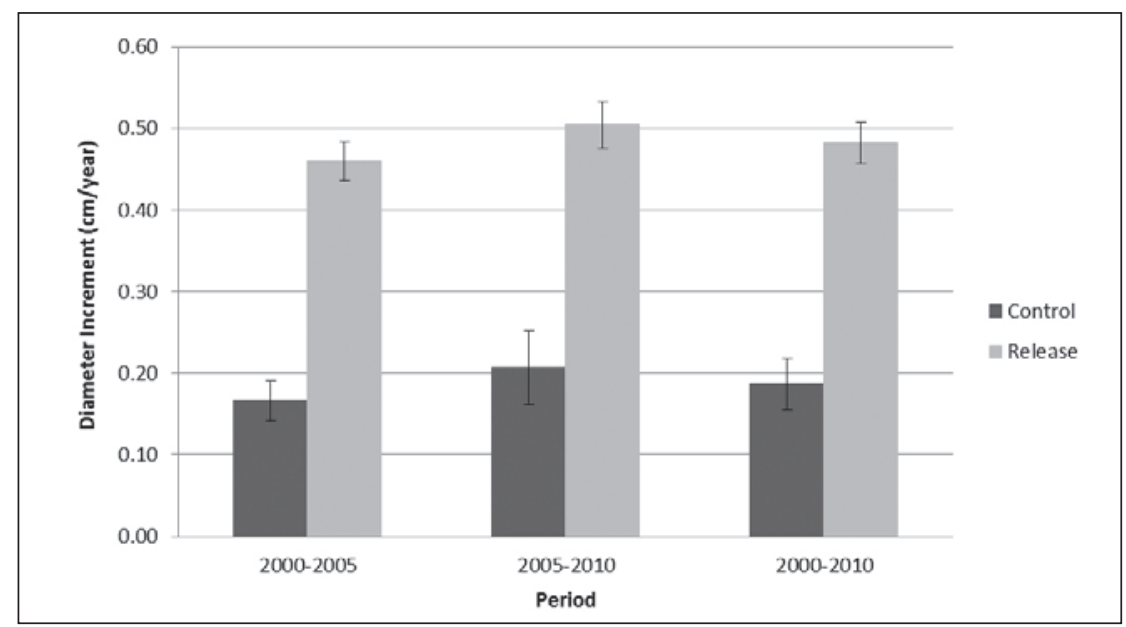

Fig. 7. Annual diameter growth of released and control understory white spruce. Error bars represent the $95 \%$ confidence interval.

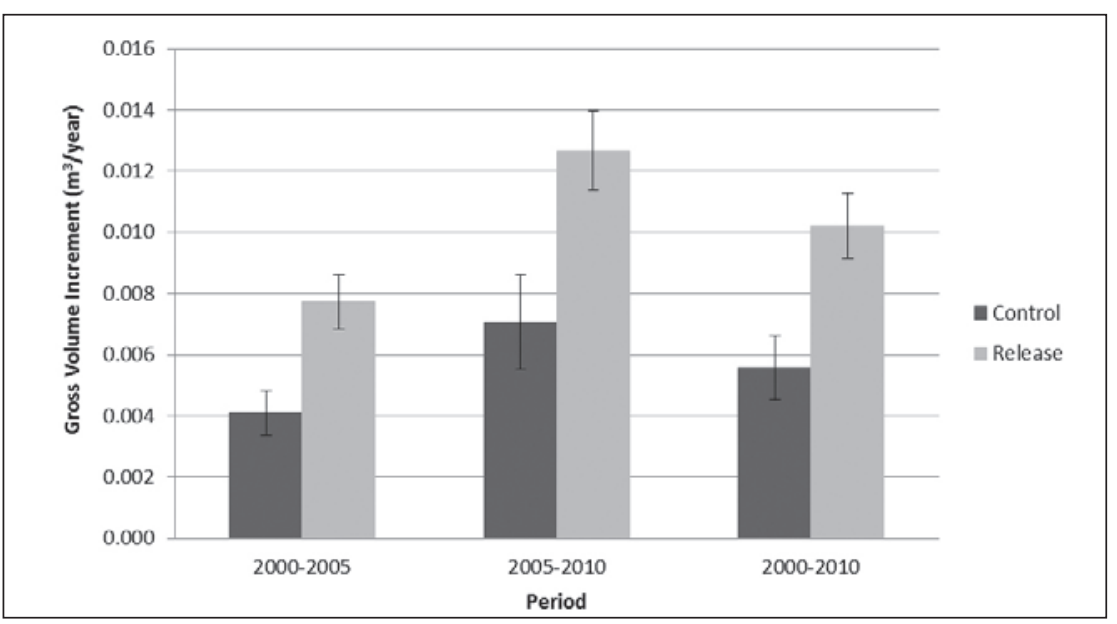

average density of 9267 stems/ha and an average top height of $8.16 \mathrm{~m}$ at age 14 .

\section{Modeling}

Using MGM, future height, diameter and merchantable volume predictions for the different strata as well as composite yield curves were developed. Fig. 11 and Fig. 12 show the influence of MGM's adjacency function on white spruce and aspen volume, respectively. The white spruce volume is slightly decreased due to the shading effect by the residual aspen when modelled with adjacency. A more pronounced suppression on the regenerating aspen can be seen due to the shading effect of the taller white spruce understory.

Volume predictions of the various strata after strip understory protection harvest, i.e., released spruce, regenerating aspen, residual aspen and spruce under residual aspen, are shown in Fig. 13. Each component was modelled separately and presented as volume per hectare. The volumes of these various strata can be combined (areaweighted) to create yield curves with or without (Fig. 14) adjacency.

Actual height growth of the control and released white spruce over the 10 year period, compared against MGM projections for control and released spruce, are shown in Fig. $15^{4}$. While the model predicts the height increments for the control well, the accelerated height growth for released spruce is underestimated if modelled at site index 14 , which is the average site index for white spruce in Alberta-Pacific's FMA area. The model can predict release close to the actual when the site index is increased to 18. Similar trends can be seen for diameter growth (Fig. 16) where growth for the control is predicted very well, but the site index must be increased to 24 to align predicted with actual diameter growth. Volume predictions (Fig. 17) behave in a similar fashion to diameter predictions with modelled growth approximating actual growth when a site index of 24 is used.

\section{Discussion \\ Benefit of operations}

Fig. 8. Annual gross volume increment of released and control understory white spruce. Error bars represent the 95\% confidence interval.

5583 stems/ha to 15380 stems/ha, average top height ranged from $5.83 \mathrm{~m}$ to $9.16 \mathrm{~m}$.
White spruce understory protection is an important tool to maximize stand yield in FMA areas where both deciduous and coniferous volumes are of interest. Since the white spruce

${ }^{4}$ The data represented here should be viewed with caution since the following comparisons of model predictions versus actual reflect the growth of only one stand. 


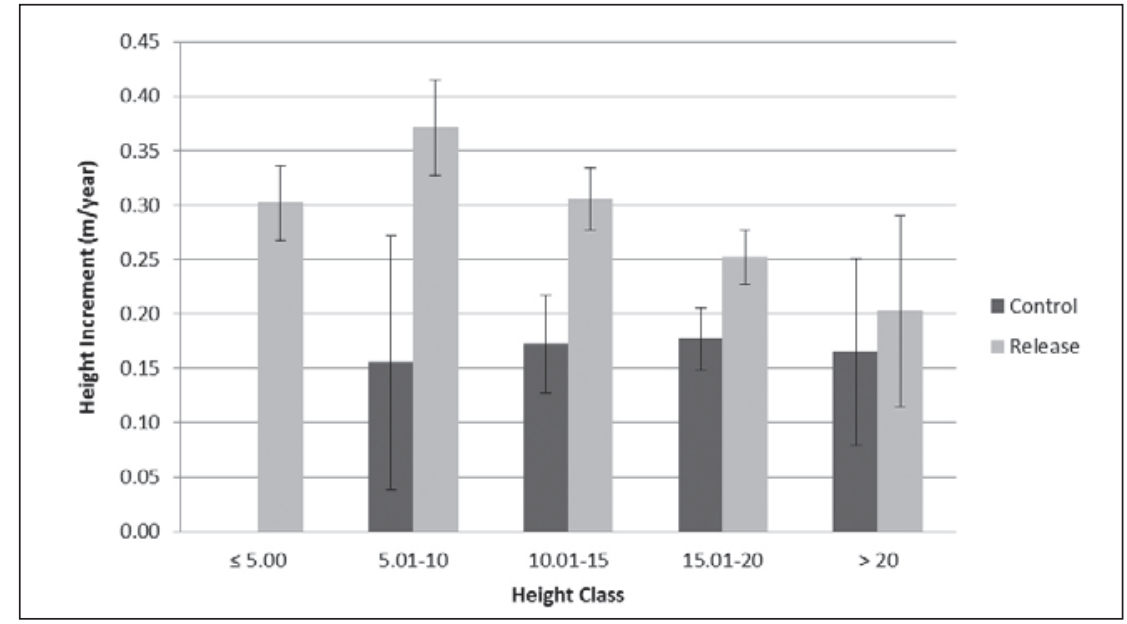

Fig. 9. Annual height increment (2000-2010) of released white spruce and control by height class. Error bars represent the 95\% confidence interval.

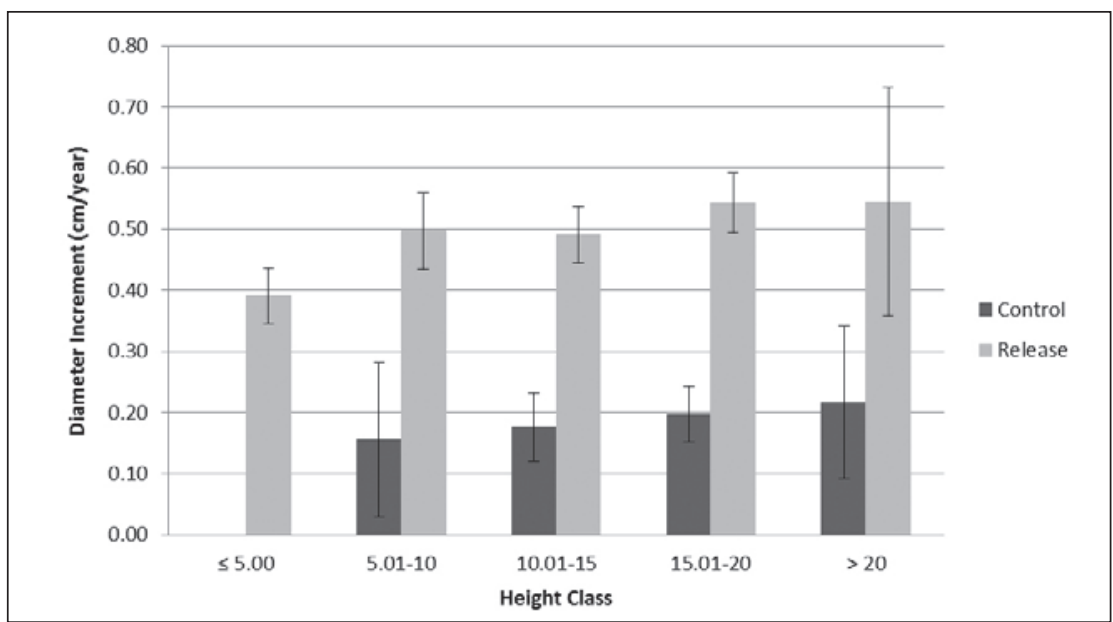

Fig. 10. Annual diameter increment (2000-2010) of released white spruce and control by height class. Error bars represent the $95 \%$ confidence interval.

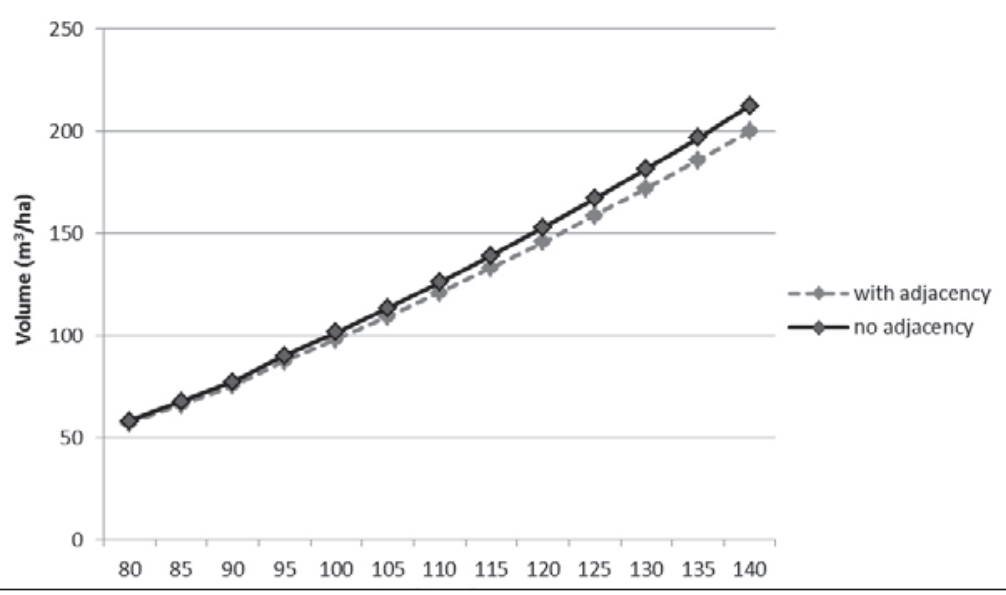

Fig. 11. Forecasted merchantable white spruce volume in extraction areas with and without the influence of shading by adjacent residual aspen. understory is not merchantable when the deciduous overstory is at its maximum mean annual increment (MAI) and the deciduous overstory will be decadent when the white spruce is at its maximum MAI, volume of either species will be lost if the stand is clearcut at either species' MAI culmination age. A two-stage harvest design such as strip cut understory protection can optimize the yield of both species. Using this approach, $86 \%$ of the aspen canopy can be harvested at maximum yield while protecting up to $71 \%$ of the understory conifer. An added benefit is that white spruce is released and growth rates can accelerate significantly, either increasing piece size or making the conifer volume available at an earlier date. Additionally, instead of incurring costs for site preparation, planting and tending, the protected understory white spruce is available to grow unimpeded by competition. Harvesting costs increase due to layout of machine corridors and lower machine productivity; however, they are minor compared to silviculture cost savings. Allowing aspen to sucker on the machine corridors and decking areas contributes to the development of a mixedwood stand and future deciduous volume. Conifer would not be harvested until the regenerating aspen is merchantable, harvesting both the mature conifer understory and regenerated aspen at the same time. Retaining white spruce seed trees at the time of final harvest and allowing the cutblock to regenerate back to deciduous will increase the likelihood of creating a stand similar to what was originally encountered. Rotating stands between a coniferous- and deciduousdominated system mimics natural stand dynamics and as such maintains important elements of the boreal ecosystem. Compared to white spruce monocultures occurring on plantations, site characteristics in these mixedwood stands may be improved through decreased risk of soil acidification and increased nutrient cycling (Kelty 1992). White spruce establishing under an aspen nurse crop are protected from climatic impacts such as late spring frost, strong winds, hail (Man and Lieffers 1999, Filipescu and Comeau 2007) and experience fewer attacks from insects such as spruce budworm and terminal weevil (MacLean 1966, Taylor et al. 1996).

\section{Impact on growth}

Released white spruce responded dramatically over the 10 year period since 


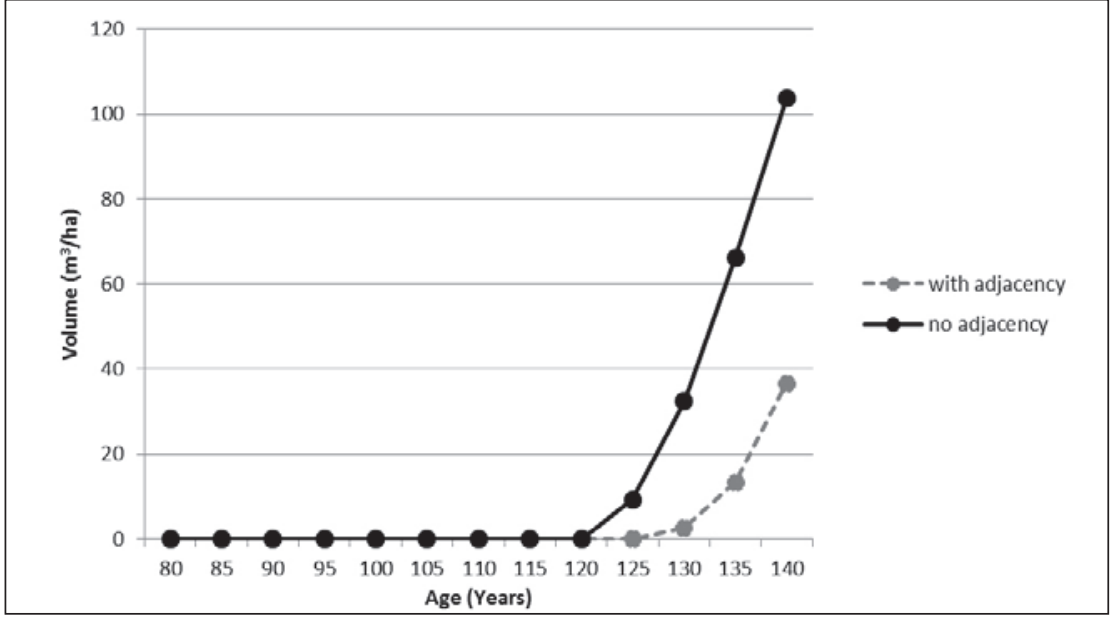

Fig. 12. Forecasted merchantable regenerating aspen volume in machine corridors with and without the influence of shading by adjacent understory white spruce.

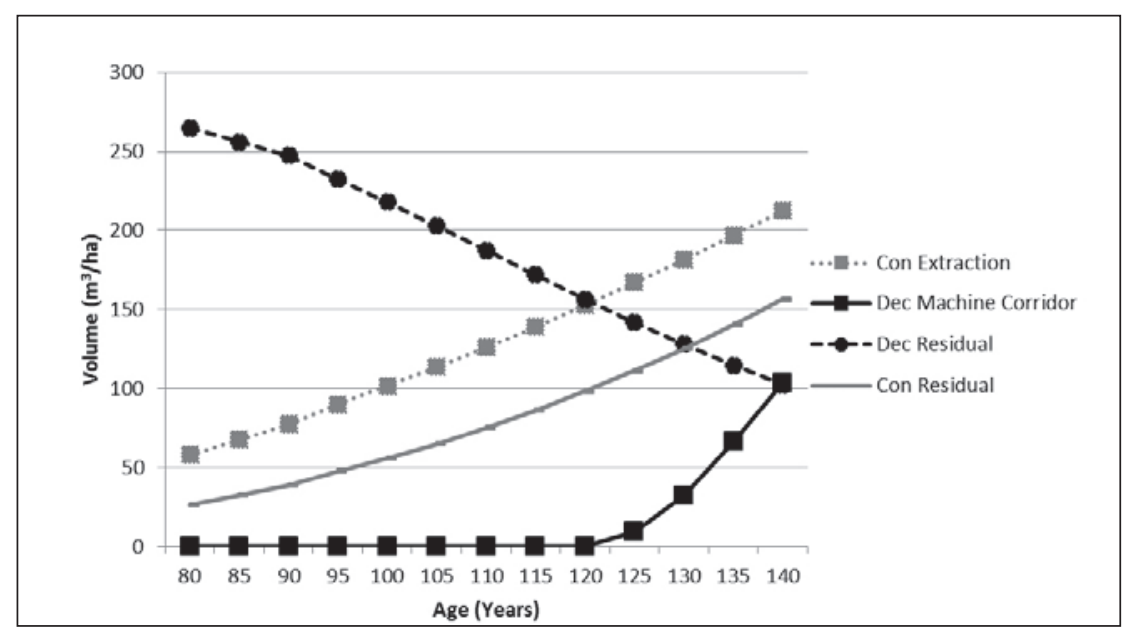

Fig. 13. Merchantable volume forecast of three strata post-harvest understory protection: released spruce (Con Extraction), regenerating aspen (Dec Machine Corridor), and residual aspen (Dec Residual) and spruce (Con Residual).

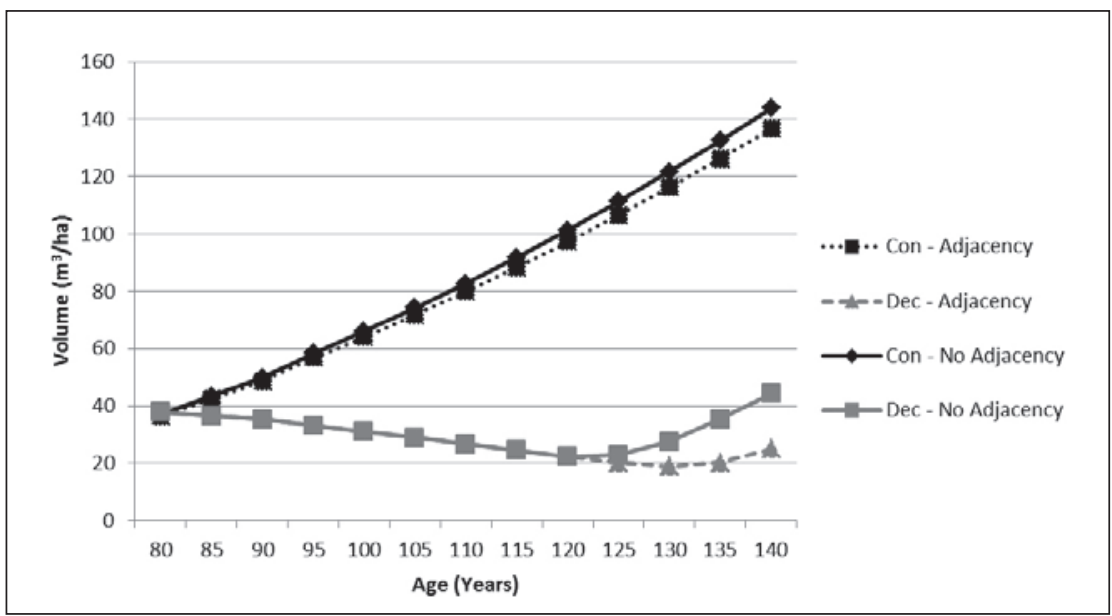

Fig. 14. Composite yield curve for conifer (Con) and deciduous volume (Dec) as forecasted by MGM with and without adjacency. understory protection harvest in this study. As reported in the literature (Man and Greenway 2004), the data presented in this paper demonstrated that diameter increment was the most responsive with a rise of $152 \%$. Height increment increased $76 \%$ over the control and total annual volume increment was elevated by $83 \%$. These are in range with other published values. Lees (1966) reported a $62 \%$ increase in diameter growth and a $57 \%$ increase in height growth after 10 years as compared to un-released trees. Steneker (1967) found that height increments doubled in released trees. Yang (1989) published results from Saskatchewan and Manitoba 30 years after release and found that diameter increment had increased by $177 \%$, height by $42 \%$ and total annual volume increment by $93 \%$ as compared to un-released trees. A similar study in Alberta (Yang 1991) showed an increase in diameter increment of $41 \%$, height increment of $38 \%$ and volume of $82 \%$. A stronger response of diameter growth to overstory removal can be expected since trees tend to grow roots and bole when subjected to wind stress and sway (Liu et al. 2003).

Aspen regeneration was deemed adequate when assessed at year 14; however, the future viability of the regenerating aspen and whether they will reach merchantability has been questioned due to shading by the retained spruce (Lennie et al. 2009).

\section{Potential yield implications}

MGM is a model that is ideally suited to forecast development of complex stands after understory protection harvest as it has the ability to predict the growth of various strata independently and combine them into area-weighted conifer and deciduous yield curves. It can also account for the spatial arrangement of the strata, incorporating the effect of one stratum on another. Since this is based on a light model, the adjacency model is in fact suppressing growth through shading.

To this point, modelling of white spruce growth response to overstory removal or release is based on only a few datasets. Release is a complex phenomenon and dependent on many variables. As shown, release can depend on initial spruce height, and it is most likely influenced by spruce density and intra-species competition. The degree of suppression prior to harvest and site productivity are 


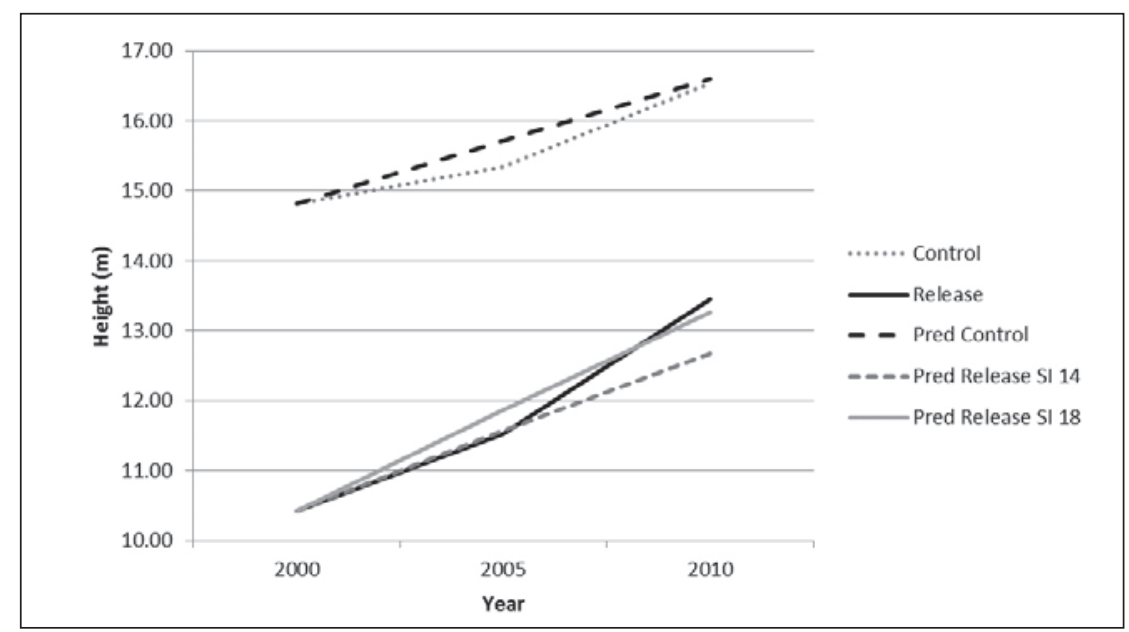

Fig. 15. Actual and predicted height growth of control and released white spruce.

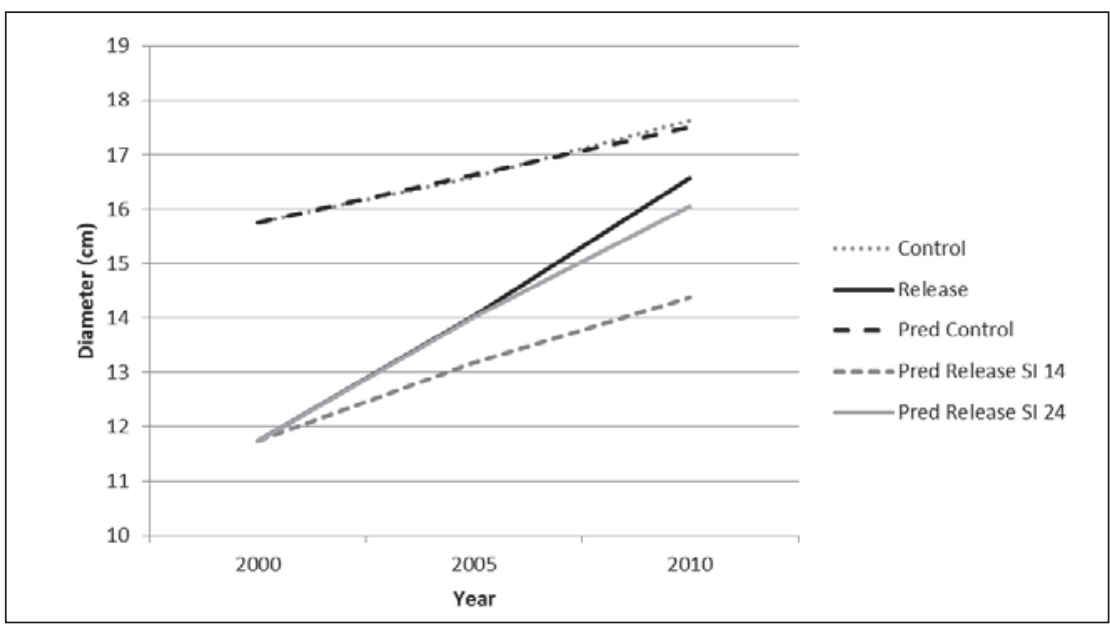

Fig. 16. Actual and predicted diameter growth of control and released white spruce.

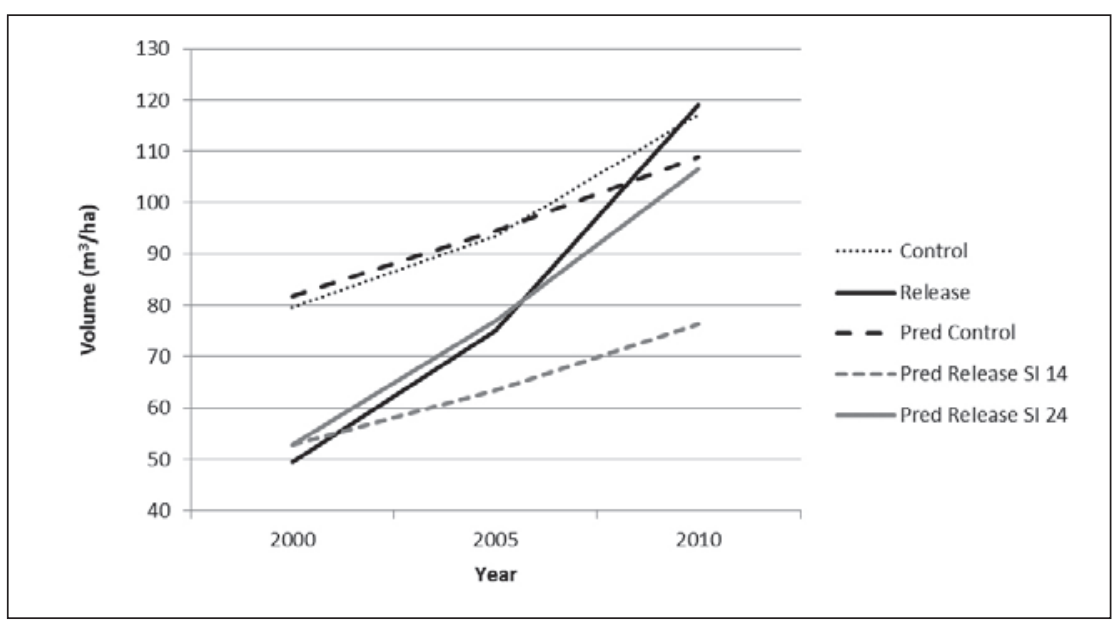

Fig. 17. Actual and predicted merchantable volume increment of control and released white spruce. additional factors that have to be taken into account. Another challenge is the determination of site index for suppressed trees following release. Using total height and age of the released conifers to calculate site index is inaccurate since their height even several years post-harvest still carries the legacy of the previously suppressed growth, hence the model's inability to account for the full extent of growth acceleration. A site index collected from open grown spruce that are of comparable height may more accurately reflect the future growth of released white spruce understory. However, these trees are difficult to find in the boreal mixedwood forest where aspen almost always influences juvenile white spruce growth in some form or another.

MGM predicts approximately $40 \mathrm{~m}^{3}$ / ha of merchantable deciduous volume from machine corridors. When adjacency is turned on, the volume is reduced to just over $20 \mathrm{~m}^{3} / \mathrm{ha}$. This reduction is predicted based solely on light availability, but other factors such as browse may cause further decline of future aspen volume. It is important to study the long term impacts on aspen growth in multiple understory protection stands since there can be high variability of machine corridor width and orientation as well as spruce density, distribution and height from site to site which will affect aspen growth differently.

\section{Understory protection as a management tool}

Harvest practices and a divided tenure for fibre have tended to un-mix the mixedwood forest due to the desire to maximize individual component volume, minimize rotation age, minimize cost, and simplify management. However, since mixedwoods have been reported to produce more combined volume than single species stands (Man and Lieffers 1999, MacPherson et al. 2001, Comeau et al. 2005), it would be prudent to take advantage of the potential for increased stand productivity now that partial harvest systems are operationally feasible. Despite the described benefits of understory protection, implementation is logistically challenging when the landbase is split between coniferous and deciduous operators and ownership is based on dominant species. Stands would be traded back and forth between 
operators since leading species alternate in the understory protection scenario, and it would be difficult to assign additional harvest costs and silviculture costs savings. Planning should not be segregated by tenure holder but instead evaluated at the landscape level to assess potential yield implications when species compositions change due to succession or management practices. Understory protection harvest combined with a common landbase approach, without land tenure concerns, would allow for the simultaneous management of both species and would be a far more efficient system to maximize stand productivity and minimize logistics.

\section{References}

Alberta Environment and Sustainable Resource Development. 2011. Reforestation Standard of Alberta. Publication No. T/268. Government of Alberta, Department of Environment and Sustainable Resource Development, Edmonton, AB. 231 p.

Bokalo, M., K.J. Stadt, P.G. Comeau and S.J. Titus. 2013. The validation of the Mixedwood Growth Model (MGM) for use in forest management decision making. Forests 4: 1-27.

Brace, L.G. and I.E., Bella. 1988. Understanding the understory: dilemma or opportunity. In J.K. Samoil (ed.). Management and utilization of northern mixedwoods. pp. 69-98. Can. For. Serv., Edmonton, AB. Info Rep. NOR-X-296.

Chen, H.Y. H. and R.V. Popadiouk. 2002. Dynamics of North American boreal mixedwoods. Environ. Rev. 10: 137-166.

Comeau P.G., R. Kabzems, J. McClarnon and J.L. Heineman. 2005. Implications of selected approaches for regenerating and managing western boreal mixedwoods. For. Chron. 81: 559-574.

Filipescu, C.N. and P.G. Comeau. 2007. Competitive interactions between aspen and white spruce vary with stand age in boreal mixedwoods. For. Ecol. Manage. 247: 175-184.

Huang, S. 1994. Ecologically based individual tree volume estimation for major Alberta tree species. Report \#1. Individual tree volume estimation procedures for Alberta: methods of formulation and statistical foundations. Alberta Environmental Protection, Land and Forest Services, Forest Management Division, Edmonton, AB.

Huang, S. 1997. A subregion-based compatible height and site index model for young mature white spruce in Alberta. Forest Management Research Note. Alberta Environmental Protection Land and Forest Service, Edmonton, AB. Publication NO. T/354.

Huang, D., S.J. Titus and D.J. Morgan 1997. A Compatible Height Site Index Age Model for Young and Mature Aspen Based on Natural Subregions. Forest Management Research Note. Alberta Environmental Protection Land and Forest Service, Edmonton, AB. Publication No. T/355.

Johnson, E.A. 1992. Fires and vegetation dynamics: studies from the North American boreal forest. Cambridge University Press, Cambridge, UK

Keddy, T. and D. Sidders. 2007. Establishment Report: Understory protection and release, and overstory fibre recovery. From FRIAAOF03-NARCAN-01 Adaptive management of mixedwoods to maximize fibre recovery and retained stem volume growth and ecosystem sustainability. p. 142. Canadian Wood Fibre Centre, Canadian Forest Service, Edmonton, AB.

Kelty, M.J. 1992. Comparative productivity of monocultures and mixed species stands. In M.J. Kelty, B.C. Larson and C.D. Oliver (eds.). The ecology and silviculture of mixed-species forests. pp. 125-141. Kluwer Academic Publishers. Dordrecht. 287 p.
Lees, J. C. 1966. Release of white spruce from aspen competition in Alberta's spruce-aspen forest. Can. Dep. For., For. Res. Branch. Ottawa. Ontario. Publ. 1163.

Lennie, A.D., S.M. Landhausser, V.J. Lieffers and D. Sidders. 2009. Regeneration of aspen following partial and strip understory protection harvest in boreal mixedwood forests. For. Chron. 85: 631-638.

Lieffers, V.J. and K.J. Stadt. 1994. Growth of understory Picea glauca, Calamagrostis canadensis, and Epilobium angustifolium in relations to overstorey light transmission. Can. J. For. Res. 24: 1193-1198.

Liu, X., U. Silins, V.J. Lieffers and R. Man. 2003. Stem hydraulic properties and growth in lodgepole pine stands following thinning and sway treatment. Can. J. For. Res. 33: 1295-1303.

MacIsaac, D.A. and R. Krygier 2009. Development and long-term evaluation of harvesting patterns to reduce windthrow risk of understorey spruce in aspen-white spruce mixedwood stands in Alberta, Canada. Forestry 82 (3): 323-341.

MacLean, D.A. 1996. Forest management strategies to reduce spruce budworm damage in the Fundy model forest. For. Chron. 72: 399-405 MacPherson, D.M., V.J. Lieffers and P.V. Blenis. 2001.Productivity of aspen stands with and without a spruce understory in Alberta's boreal mixedwood forests. For Chron. 77: 351-357.

Man, R. and K.J. Greenway 2004. Meta-analysis of understory white spruce response to release from overstory aspen. For. Chron. 80: 694-704

Man, R. and V.J. Lieffers. 1999. Are mixtures of aspen and white spruce more productive than single species stands? For. Chron. 75: 505-513

Navratil, S., L.G. Brace, E.A. Sauder and S. Lux. 1994. Silvicultural and harvesting options to favor immature white spruce and aspen regeneration in boreal mixedwoods. Can. For. Serv., North. For. Centre, Edmonton, AB. Inf. Rep. NOR-X-327.

Rowe, J.S. and G.W. Scotter. 1973. Fire in the boreal forest. Quart. Res. 3: 444-464.

Sauder, T. 1992. Timber-harvesting techniques that protect conifer understory in mixedwood stands: Case studies. Forest Engineering Research Institute of Canada. Vancouver, B.C. Joint publication of the Canadian Forestry Service and the Alberta Forest Service. Proj. No. $1480.72 \mathrm{p}$.

Stadt, K.J. and V.J. Lieffers. 2000. MIXLIGHT: a flexible light transmission model for mixed-species forest stands. Agric. For. Meteorol. 102: 235-252.

Steneker, G.A. 1963. Results of a 1936 release cutting to favor white spruce in a 50-year-old white spruce-aspen stand in Manitoba. Can. Dep. For., For. Res. Branch, Ottawa, Ontario. Publ. 1005. 17 p.

Steneker, G. A. 1967. Growth of white spruce following release from trembling aspen. Can. Dep. Rural Dev., For. Res. Branch, Ottawa, Ontario. Publ. 1183. 16 p.

Taylor, S.P., R.I. Alfaro, C. DeLong and L. Rankin. 1996. The effects of overstory shading on white pine weevil damage to white spruce and its effect on spruce growth rates. Can. J. For. Res. 26: 306-312.

Yang, R. C. 1989. Growth response of white spruce to release from trembling aspen. For. Can., North. For. Cent., Edmonton, AB. Inf. Rep. NOR-X-302.

Yang, R.C. 1991. Growth of white spruce following release from aspen competition: 35 year results. For. Chron. 67: 706-711. 